\title{
Reduced Expression of the Tomato Ethylene Receptor Gene LeETR4 Enhances the Hypersensitive Response to Xanthomonas campestris pv. vesicatoria
}

\author{
Joseph A. Ciardi, ${ }^{1}$ Denise M. Tieman, ${ }^{1}$ Jeffrey B. Jones, ${ }^{2}$ and Harry J. Klee ${ }^{1}$ \\ ${ }^{1}$ Horticultural Sciences Department, P.O. Box 110690, University of Florida, Gainesville 32611-0690, U.S.A.; \\ ${ }^{2}$ Department of Plant Pathology, University of Florida, Gainesville 32611-0680, U.S.A. \\ Accepted 8 November 2000.
}

The hypersensitive response (HR) involves rapid death of cells at the site of pathogen infection and is thought to limit pathogen growth through the plant. Ethylene regulates senescence and developmental programmed cell death, but its role in hypersensitive cell death is less clear. Expression of two ethylene receptor genes, $N R$ and LeETR4, is induced in tomato (Lycopersicon esculentum cv. Mill) leaves during an HR to Xanthomonas campestris pv. vesicatoria, with the greatest increase observed in LeETR4. LeETR4 antisense plants previously were shown to exhibit increased sensitivity to ethylene. These plants also exhibit greatly reduced induction of LeETR4 expression during infection and an accelerated HR at inoculum concentrations ranging from $10^{5}$ to $10^{7} \mathrm{CFU} / \mathrm{ml}$. Increases in ethylene synthesis and pathogenesis-related gene expression are greater and more rapid in infected LeETR4 antisense plants, indicating an enhanced defense response. Populations of avirulent $X$. campestris pv. vesicatoria decrease more quickly and to a lower level in the transgenic plants, indicating a greater resistance to this pathogen. Because the ethylene action inhibitor 1-methylcyclopropene alleviates the enhanced HR phenotype in LeETR4 antisense plants, these changes in pathogen response are a result of increased ethylene sensitivity.

The hypersensitive response (HR) to pathogens results in a small area of dead cells at the site of infection surrounded by healthy, living tissue. Hypersensitive cell death may directly limit the spread of the pathogen through the plant and is often associated with disease resistance (Goodman and Novacky 1994). Although several potential mechanisms for regulating the HR have been identified, it is still not clear how a plant limits cell death to the infection site. Some of the earliest events in the defense response include ion flux across plasma membranes (Jabs et al. 1997; Mittler et al. 1995), production of reactive oxygen intermediates (Glazener et al. 1996; Levine et al. 1994), and activation of protein kinase-mediated phosphorylation cascades (Ligterink et al. 1997; Romeis et al. 1999; Zhou et al. 1995). These responses are often essential, but not sufficient, to cause cell death. Other factors such as increases in nitric oxide and salicylic acid (SA) also are

Corresponding author: H. J. Klee, E-mail: hjklee@gnv.ifas.ufl.edu sometimes necessary for death to occur (Delledonne et al. 1998; Shirasu et al. 1997). Synergistic effects among SA, nitric oxide, and reactive oxygen intermediates suggest a positive feedback loop that rapidly amplifies the defense signal, leading to the HR (McDowell and Dangl 2000).

Ethylene's role in promoting senescence (Grbic and Bleecker 1995) and developmentally regulated programmed cell death (He et al. 1996; Young and Gallie 1999) makes it a likely candidate as a regulator of pathogen-induced cell death as well. The effect of ethylene insensitivity on pathogen resistance, however, varies greatly from one disease organism to another. The ethylene insensitive Arabidopsis spp. mutant ein2 is more susceptible to a normally avirulent strain of the fungus Botrytis cinerea (Thomma et al. 1999). Similarly, a soybean (Glycine max) mutant with reduced ethylene sensitivity exhibits greater susceptibility to the avirulent fungal pathogen Phytophthora sojae (Hoffman et al. 1999). Ethylene insensitivity, however, had no effect on resistance to Pseudomonas syringae pv. tomato (Bent et al. 1992), Peronospora parasitica, or Alternaria brassicicola in Arabidopsis spp. (Thomma et al. 1999) or P. syringae pv. glycinea in soybean (Hoffman et al. 1999). The role of ethylene in compatible interactions varies as well. In soybean, for example, ethyleneinsensitive mutants displayed less severe symptoms to virulent $P$. syringae pv. glycinea and $P$. sojae, but more severe symptoms to virulent Septoria glycines and Rhizoctonia solani (Hoffman et al. 1999).

In tomato (Lycopersicon esculentum cv. Mill), a dominant mutation in the ethylene receptor gene $N R$ causes ethylene insensitivity throughout development (Lanahan et al. 1994). Furthermore, the $\mathrm{Nr}$ mutant exhibits reduced necrosis in response to the virulent bacterial pathogen Xanthomonas campestris pv. vesicatoria, the causal agent of bacterial spot (Lund et al. 1998). This response indicates that reduced ethylene sensitivity can reduce cell death caused by this pathogen and that ethylene receptors may be involved in regulating pathogen-induced cell death in wild-type plants.

Ethylene receptors are encoded by multigene families in Arabidopsis spp. (Chang et al. 1993; Hua et al. 1995; Hua et al. 1998) and tomato (Lashbrook et al. 1998; Tieman and Klee 1999; Wilkinson et al. 1995). Combining loss-of-function mutations in four of the Arabidopsis spp. ethylene receptors (ETR1, EIN4, ERS2, and ETR2) in a single plant caused strong constitutive ethylene responses, indicating that these 
receptors are negative regulators of ethylene response (Hua and Meyerowitz 1998). In tomato, five ethylene receptor genes have been identified: LeETR1, LeETR2, NR, LeETR4, and LeETR5. Reduced expression of LeETR4 in transgenic tomato plants increased sensitivity to ethylene, whereas overexpression of the wild-type $N R$ gene decreased ethylene sensitivity (Ciardi et al. 2000; Tieman et al. 2000). Therefore, these receptors negatively regulate ethylene response. These results also suggest that a plant can regulate ethylene sensitivity through changes in receptor-gene expression.

Similar to the $\mathrm{Nr}$ mutant, plants overexpressing wild-type $N R$ exhibited reduced necrosis during infection with virulent $X$. campestris pv. vesicatoria, indicating that increased wildtype receptor levels reduce ethylene sensitivity and cell death (Ciardi et al. 2000). In leaves of wild-type plants, an approximately 30-fold induction of LeETR4 gene expression and a threefold induction of $N R$ gene expression occurs during compatible and incompatible interactions with $X$. campestris pv. vesicatoria. The induction of both genes occurs much more quickly during the incompatible interaction, suggesting that this induction may be involved in regulating the defense response.

Here we have analyzed the response to $X$. campestris pv. vesicatoria in LeETR4 antisense (LeETR4AS) plants. The transgenic plants have greatly reduced induction of LeETR4 gene expression during infection with an avirulent strain of this pathogen. Reducing expression of this gene leads to an enhanced HR and stronger resistance. Therefore, induction of these genes in wild-type plants may limit hypersensitive cell death by decreasing ethylene sensitivity in cells surrounding the infection site.

\section{RESULTS}

Induction of LeETR4 expression in leaves during an incompatible interaction with $X$. campestris pv. vesicatoria is reduced in LeETR4AS plants.

We have previously shown that infection with an avirulent strain of $X$. campestris pv. vesicatoria strongly induces LeETR4 gene expression in leaves (Ciardi et al. 2000). To determine whether this induction plays a role in the resistance response, we compared the HR to $X$. campestris pv. vesicatoria in wild-type and LeETR4AS plants. Four-week-old plants were infiltrated with inoculum containing $10^{7} \mathrm{CFU} / \mathrm{ml}$ of an avirulent strain (Xv 87-7) of this pathogen. In wild-type leaves, LeETR4 mRNA levels increased fivefold $48 \mathrm{~h}$ after inoculation and peaked $72 \mathrm{~h}$ after inoculation at an almost 30fold induction (Fig. 1). In LeETR4AS plants, LeETR4 mRNA did not begin to increase until $72 \mathrm{~h}$ after inoculation, and peak levels of LeETR4 mRNA were reduced 74 to $93 \%$ relative to wild type. Therefore the induction of LeETR4 expression in LeETR4AS lines was delayed and greatly reduced.

\section{Reduced LeETR4 expression results}

in more rapid and extensive cell death during infection.

Wild-type plants infiltrated with $10^{8} \mathrm{CFU} / \mathrm{ml}$ of avirulent $X$. campestris pv. vesicatoria exhibited water soaking of the entire infected area 24 to $36 \mathrm{~h}$ after inoculation. This water soaking was soon followed by confluent necrosis 48 to $60 \mathrm{~h}$ after inoculation. After infiltration with $10^{7} \mathrm{CFU} / \mathrm{ml}$, symptoms were identical to the higher inoculum but developed more slowly, resulting in confluent necrosis 84 to $96 \mathrm{~h}$ after inoculation. An inoculum concentration of $10^{7} \mathrm{CFU} / \mathrm{ml}$ was chosen to better allow for comparisons in the timing of symptom development between wild-type and LeETR4AS plants.

Reduced expression of LeETR4 resulted in accelerated necrosis in the transgenic lines. Water soaking was first observed $48 \mathrm{~h}$ after inoculation in the transgenic plants, compared with $72 \mathrm{~h}$ in the wild type. Confluent necrosis occurred 72 to $84 \mathrm{~h}$ after inoculation in antisense lines compared with $96 \mathrm{~h}$ after inoculation in the wild type (Fig. 2A). Among the three antisense lines, the one with the greatest sensitivity to ethylene (LeETR4AS-3) (Tieman et al. 2000) also exhibited the most rapid necrosis. Both vacuum infiltration with inoculum containing $0.0125 \%$ Silwet and syringe infiltration without Silwet produced identical reactions (data not shown). The remaining experiments were conducted on vacuum-infiltrated plants. To quantify the extent of cell damage, electrolyte leakage was measured in leaves of infected plants until confluent necrosis occurred. Electrolyte leakage increased more quickly in the LeETR4AS plants, further indicating more rapid cell death in these plants (Fig. 3).

Lower levels of inoculum were used to further examine response to $X$. campestris pv. vesicatoria. Ninety-six hours after infiltration with $10^{6} \mathrm{CFU} / \mathrm{ml}$, wild-type plants exhibited small distinct necrotic areas that did not expand further, whereas the antisense lines often showed confluent necrosis at this concentration (Fig. 2B). The extent of necrosis was normally greater in the antisense plants at $10^{6} \mathrm{CFU} / \mathrm{ml}$, although confluent necrosis did not develop consistently in every experiment, possibly as a result of differences in environmental conditions. At $10^{5} \mathrm{CFU} / \mathrm{ml}$, individual lesions developed more quickly on LeETR4AS leaves than on the wild type, but confluent necrosis was not observed in either genotype. At $7 \times$ magnification, lesions were first visible on the abaxial surface of LeETR4AS leaves $96 \mathrm{~h}$ after inoculation, whereas there were no lesions visible on the wild-type plants (Fig. $2 \mathrm{~F}$ and $\mathrm{G})$. At $120 \mathrm{~h}$ after inoculation, the first lesions were visible on

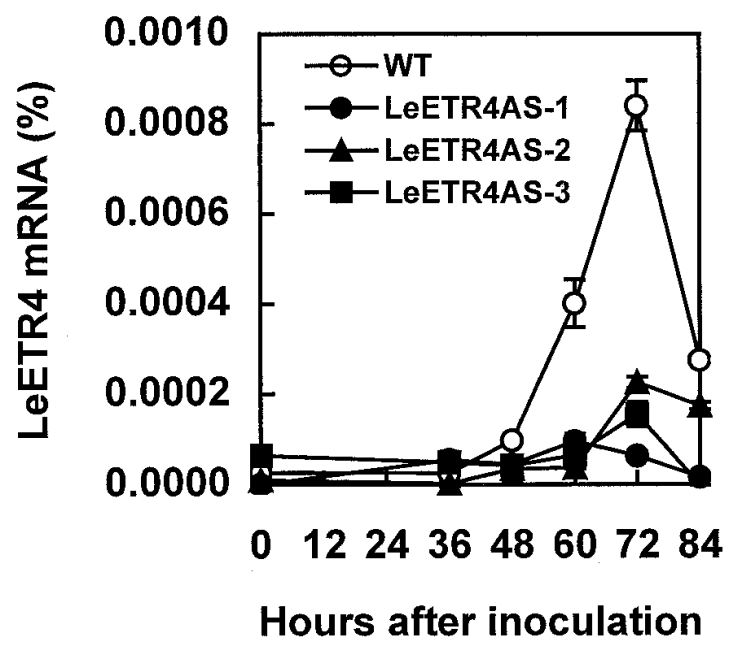

Fig. 1. LeETR4 gene expression in leaves of wild-type and LeETR4 antisense plants during an incompatible interaction with Xanthomonas campestris pv. vesicatoria. Percent of mRNA was quantified by RNase protection assays, as described in text. 
wild-type plants but were somewhat smaller and much less abundant than on LeETR4AS leaves. Trypan blue staining revealed larger areas of necrosis on LeETR4AS leaves $120 \mathrm{~h}$ after inoculation as well (Fig. $2 \mathrm{H}$ and I). At $144 \mathrm{~h}$ after inoculation, however, there was no difference in lesion size or abundance between the two genotypes (data not shown), indicating that at $10^{5} \mathrm{CFU} / \mathrm{ml}$, LeETR4 expression affected the timing but not the ultimate extent of cell death.

To determine whether accelerated necrosis in LeETR4AS plants was a result of increased susceptibility to $X$. campestris
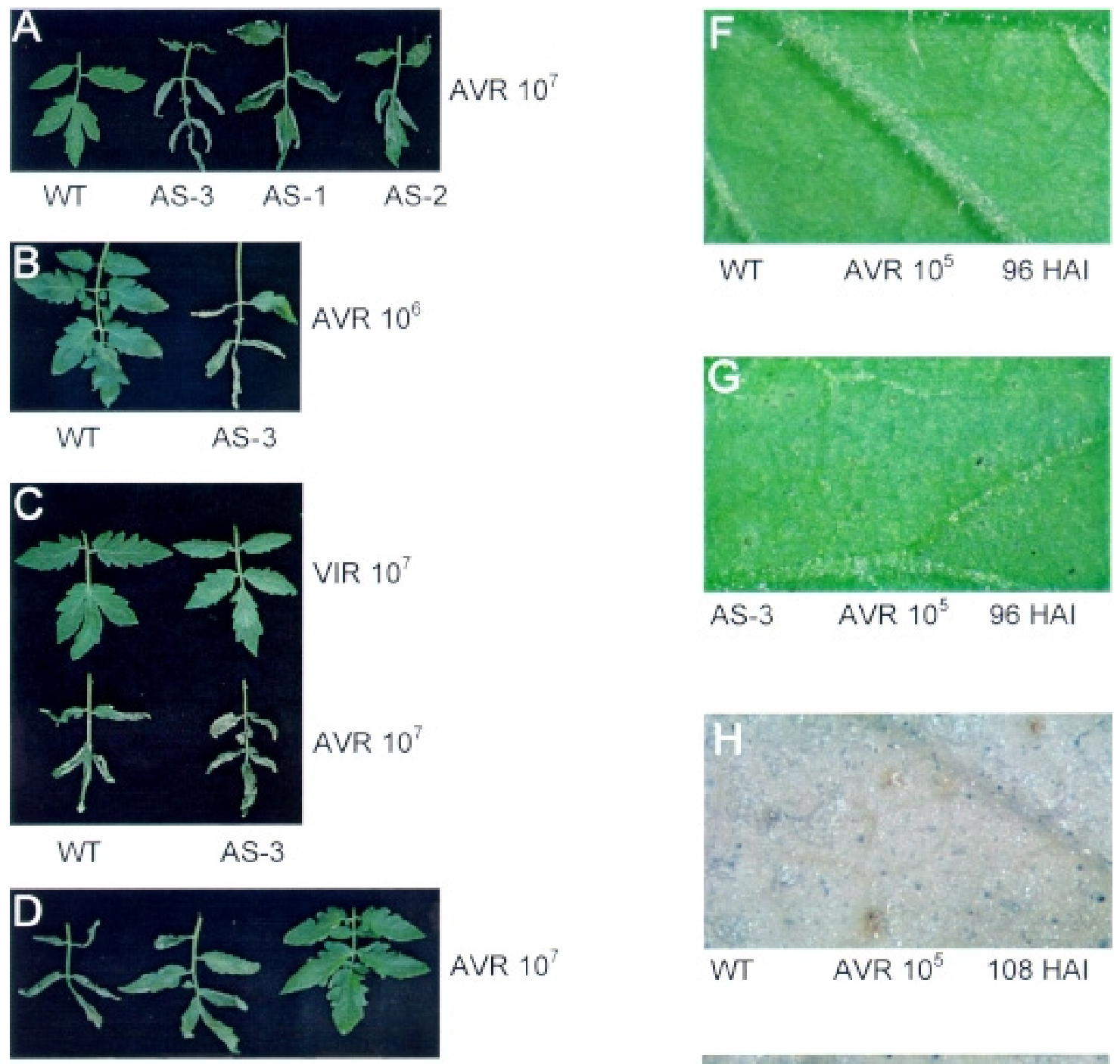

AVR $10^{7}$
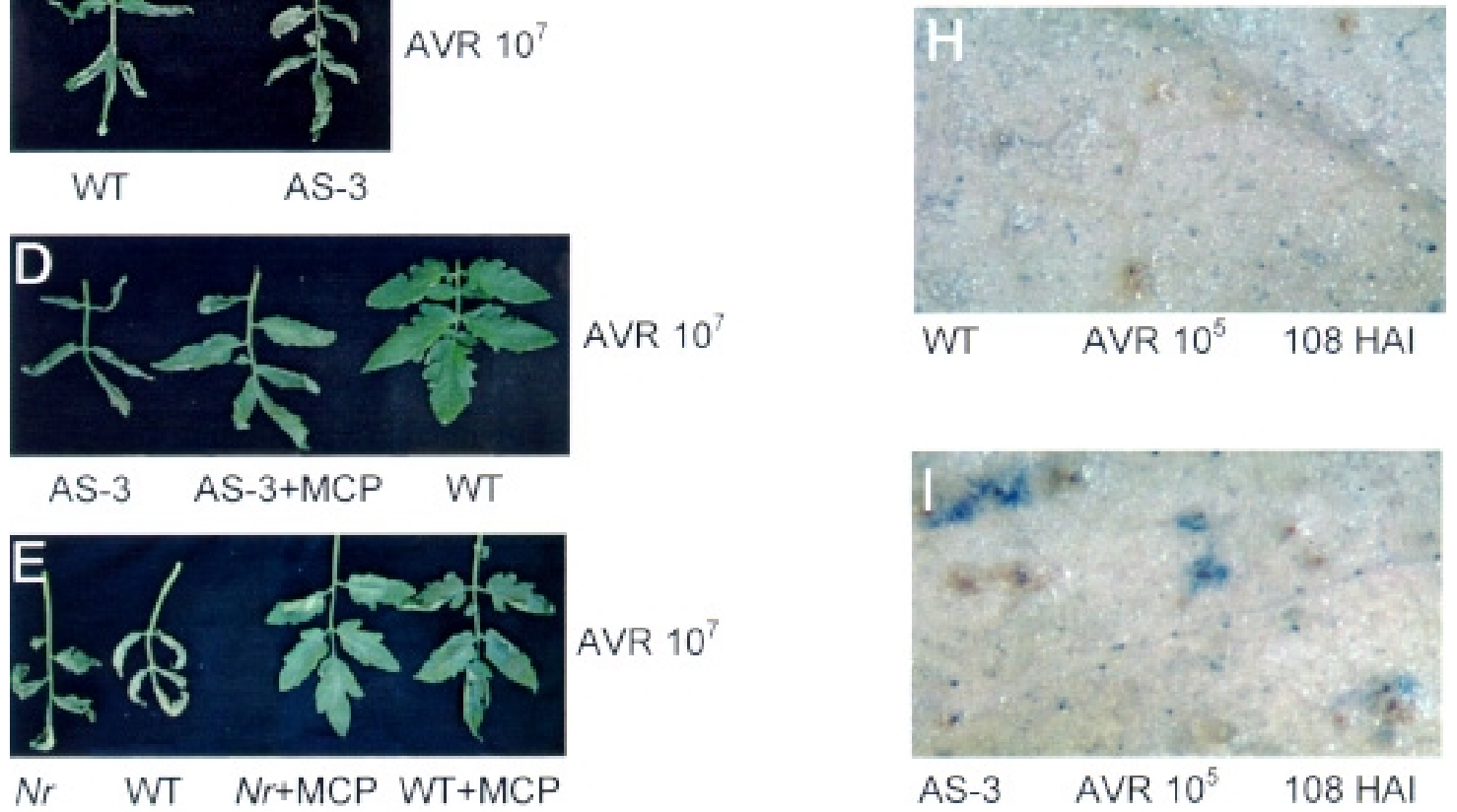

Fig. 2. Four-week-old plants infiltrated with Xanthomonas campestris pv. vesicatoria. A, Leaves of wild-type (WT) and three independent LeETR4 antisense (AS) lines infiltrated with an avirulent (AVR) strain at a concentration of $10^{7} \mathrm{CFU} / \mathrm{ml}\left(10^{7}\right), 72 \mathrm{~h}$ after inoculation (HAI). B, LeETR4 AS and WT leaves infiltrated with $10^{6} \mathrm{CFU} / \mathrm{ml}$ of an AVR strain, 96 HAI. C, LeETR4AS and WT leaves infiltrated with $10^{7} \mathrm{CFU} / \mathrm{ml}$ of virulent (VIR) or AVR strains, 96 HAI. D, LeETR4AS and WT leaves treated with the ethylene action inhibitor 1-methylcyclopropene (MCP), infiltrated with $10^{7}$ $\mathrm{CFU} / \mathrm{ml}$ of an AVR strain, $72 \mathrm{HAI}$. E, Ethylene-insensitive $N r$ mutant and wild-type leaves treated with the ethylene action inhibitor MCP before infiltration with $10^{7} \mathrm{CFU} / \mathrm{ml}$ of an AVR strain, $72 \mathrm{HAI}$. F, WT leaf infiltrated with $10^{5} \mathrm{CFU} / \mathrm{ml}$ of an AVR strain (AVR $10^{5}$ ), $96 \mathrm{HAI}$. G, LeETR4AS-3 (AS-3) leaf infiltrated with $10^{5}$ CFU/ml of avirulent strain (AVR $10^{5}$ ), 96 HAI. H, WT leaf infiltrated with $10^{5}$ CFU/ml of an AVR strain (AVR $10^{5}$ ) and stained with trypan blue, 120 HAI. I, LeETR4AS-3 (AS-3) leaf infiltrated with $10^{5}$ CFU/ml of an AVR strain (AVR 10 ) and stained with trypan blue, $120 \mathrm{HAI}$. 
pv. vesicatoria, plants were infiltrated with $10^{7} \mathrm{CFU} / \mathrm{ml}$ of a virulent strain (Xv 93-1). There was no visible necrosis in wild-type or antisense plants $96 \mathrm{~h}$ after inoculation, whereas all plants inoculated with $10^{7} \mathrm{CFU} / \mathrm{ml}$ of the avirulent strain displayed confluent necrosis at this time (Fig. 2C). Necrosis began to develop $120 \mathrm{~h}$ after inoculation with the virulent strain, but there was no significant difference in symptom development between wild-type and LeETR4AS plants. Wildtype and antisense plants dipped in inoculum levels from $10^{5}$ to $10^{8} \mathrm{CFU} / \mathrm{ml}$ of the virulent strain also showed no difference in symptoms through visual evaluation or trypan blue staining (data not shown). Therefore, reduced expression of LeETR4 did not affect susceptibility to $X$. campestris pv. vesicatoria.

\section{Ethylene inhibitor MCP delays hypersensitive cell death but the $N r$ mutation does not.}

The LeETR4AS lines show increased sensitivity to ethylene exhibited by reduced seedling length, leaf epinasty, and accelerated flower senescence (Tieman et al. 2000). These phenotypes can be alleviated by treating the plants with ethylene action inhibitors such as silver thiosulfate or 1-methylcyclopropene (MCP). MCP is thought to compete with ethylene for binding to the receptor, thereby blocking ethylene response (Sisler and Serek 1997). Alleviation of these phenotypes with ethylene action inhibitors indicates that they are caused by an increase in ethylene sensitivity and not by an ethyleneindependent function of the LeETR4 protein. To determine whether increased ethylene sensitivity also caused the enhanced HR, plants were treated with MCP for $12 \mathrm{~h}$ and then inoculated with $10^{7} \mathrm{CFU} / \mathrm{ml}$ of avirulent $X$. campestris pv. vesicatoria. MCP treatment delayed the HR in LeETR4AS plants, but the response still occurred more quickly than in untreated wild-type plants (Fig. 2D). Therefore, the ethylene action inhibitor alleviated the accelerated HR phenotype, but did not completely eliminate it.

MCP treatment also delayed the HR in wild-type plants (Fig. 2E). Ethylene-insensitive $N r$ mutant plants, however, exhibited no difference in symptom development after infiltration with $10^{7} \mathrm{CFU} / \mathrm{ml}$ of the avirulent strain (Fig. 2E) or by

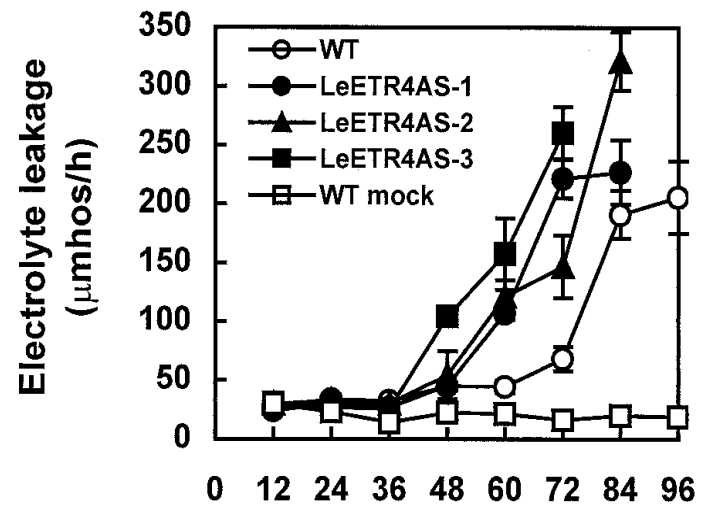

\section{Hours after inoculation}

Fig. 3. Electrolyte leakage from leaves of wild-type and LeETR4 antisense plants infected with avirulent Xanthomonas campestris pv. vesicatoria. Measurements were taken until confluent necrosis occurred in more than $75 \%$ of the infected leaves. dipping in $10^{8} \mathrm{CFU} / \mathrm{ml}$ (Ciardi et al. 2000). These results suggest that MCP-treated plants may be more insensitive to ethylene than the $\mathrm{Nr}$ mutant. To compare ethylene sensitivity in $\mathrm{Nr}$ mutant and MCP-treated wild-type plants, seedlings were grown in the presence of the ethylene precursor 1-aminocyclopropane-1-carboxylic acid (ACC). ACC is converted to ethylene by the plant and inhibits hypocotyl and root elongation (Lanahan et al., 1994). Inhibition of seedling elongation was greater in the $\mathrm{Nr}$ mutant than in the MCP-treated wild-type plants at concentrations of ACC ranging from 0.3 to $30 \mathrm{mM}$ (data not shown), indicating that MCP-treated plants are less sensitive to ethylene than the $\mathrm{Nr}$ mutant.

Increases in ethylene synthesis and PR gene expression are greater and more rapid in LeETR4AS plants.

Increases in ethylene synthesis are observed in many plantpathogen interactions and are often more rapid during incompatible interactions than they are in compatible interactions (De Laat and Van Loon 1983; Montalbini and Elstner 1977). Large increases in ethylene synthesis occurred during infection with avirulent $X$. campestris pv. vesicatoria and were correlated with the onset and spread of necrosis. In wild-type plants, ethylene levels began to increase $60 \mathrm{~h}$ after inoculation compared with $36 \mathrm{~h}$ after inoculation in the LeETR4AS plants (Fig. 4). For two of the transgenic lines (LeETR4AS-1 and LeETR4AS-3), the peak ethylene synthesis also occurred 12 to $24 \mathrm{~h}$ earlier than in the wild-type lines and was approximately threefold higher.

PR gene expression is associated with the defense response in several plant-pathogen interactions (Linthorst 1991), and these proteins play a role in resistance to specific pathogens (Broglie et al. 1991; Zhu et al. 1994). Expression of the basic, intracellular PR genes chitinase, $\beta$-1,3-glucanase, and PRIbl

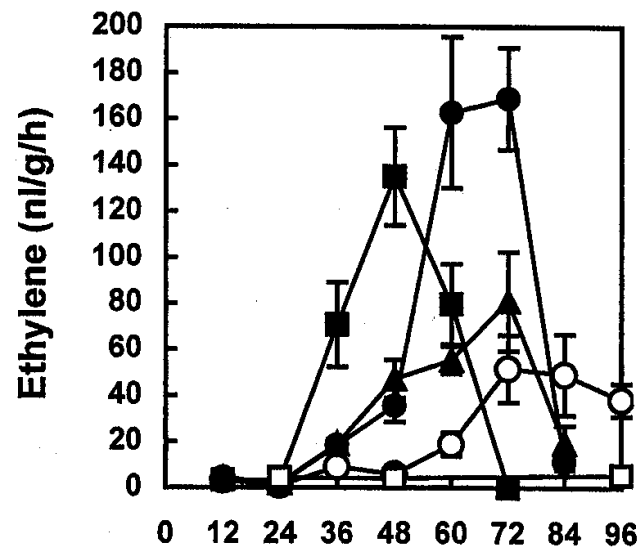

Hours after inoculation

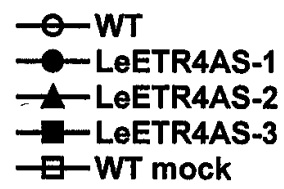

Fig. 4. Ethylene synthesis in leaves of wild-type and LeETR4 antisense plants infected with an avirulent strain of Xanthomonas campestris pv. vesicatoria. 
is induced during infection with avirulent $X$. campestris pv. vesicatoria and, for chitinase and $\beta$-1,3-glucanase, the induction of these genes is ethylene-regulated (Ciardi et al. 2000). Like ethylene synthesis, the pattern of PR gene expression indicated a stronger and more rapid activation of the defense response in two of the transgenic lines (LeETR4AS-1 and LeETR4AS-3) (Fig. 5).

Growth of an avirulent $X$. campestris pv. vesicatoria strain is reduced in LeETR4AS plants.

To determine whether the more rapid defense response in LeETR4AS lines affected resistance, we measured avirulent $X$. campestris pv. vesicatoria population levels in transgenic and wild-type plants. The plants were infiltrated with two different concentrations of inoculum, $10^{5}$ and $10^{7} \mathrm{CFU} / \mathrm{ml}$. In the wild type, bacterial populations increased to approximately $10^{7} \mathrm{CFU} / \mathrm{cm}^{2}$ of leaf tissue before beginning to decline. The decline in population levels occurred at the same

\section{Hours After Inoculation}

\section{2}

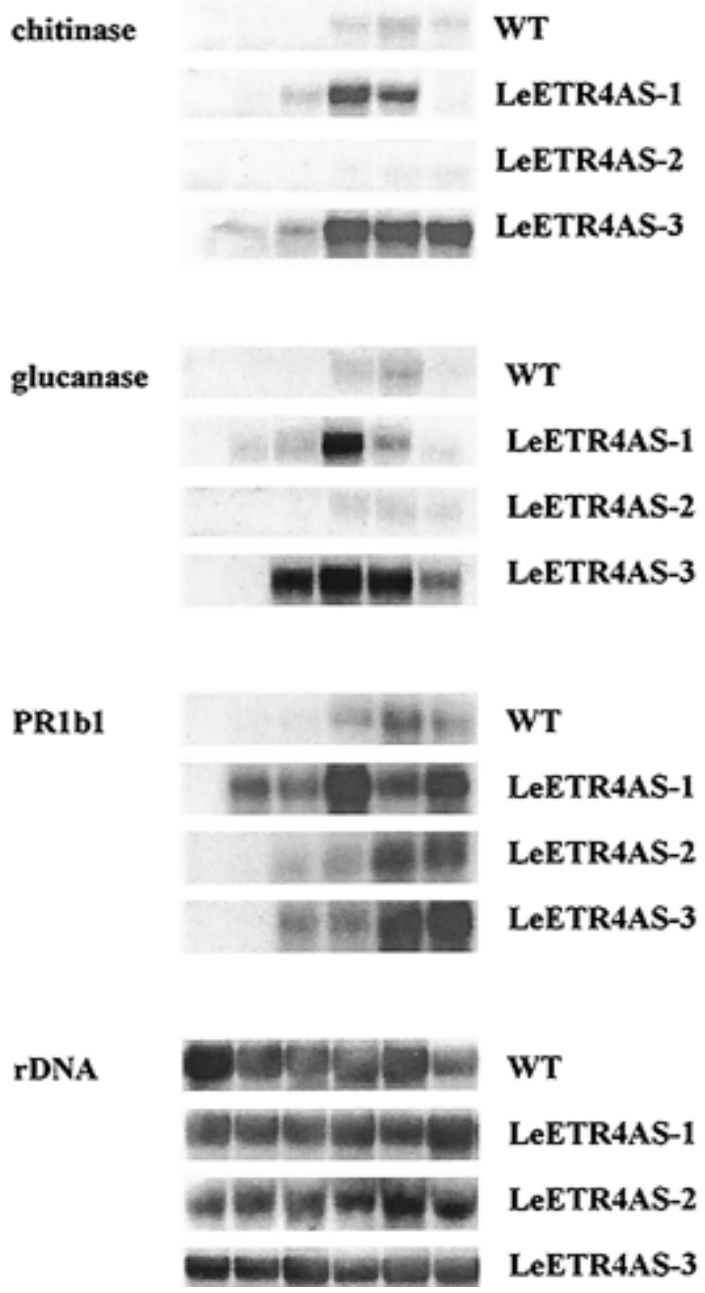

Fig. 5. Pathogenesis-related gene expression in leaves of wild-type and LeETR4 antisense plants infected with avirulent Xanthomonas campestris pv. vesicatoria. RNA was quantified by RNA gel blot analysis. time that necrosis became visible on the leaf, suggesting that plant cell death was limiting growth of the pathogen. At both concentrations of inoculum, populations declined more quickly and to a lower level in the transgenic lines than in the wild type. For example, 4 days after inoculation with $10^{7}$ $\mathrm{CFU} / \mathrm{ml}$, bacterial populations were approximately tenfold lower in LeETR4AS-3 leaves than in the wild type. Lower bacterial titers in the transgenic plants indicate that the faster, stronger defense response increased resistance (Fig. 6).

\section{DISCUSSION}

Overexpression of the wild-type ethylene receptor gene $N R$ in transgenic plants reduced ethylene response, indicating that plants may decrease ethylene sensitivity through induction of receptor gene expression. Overexpression of $N R$ also reduced the spread of necrosis during infection with a virulent strain of $X$. campestris pv. vesicatoria, indicating that induction of ethylene receptor genes also can alter pathogen response. In wild-type plants, a threefold induction of $N R$ and an approximately 30-fold induction of LeETR4 occurred during infection
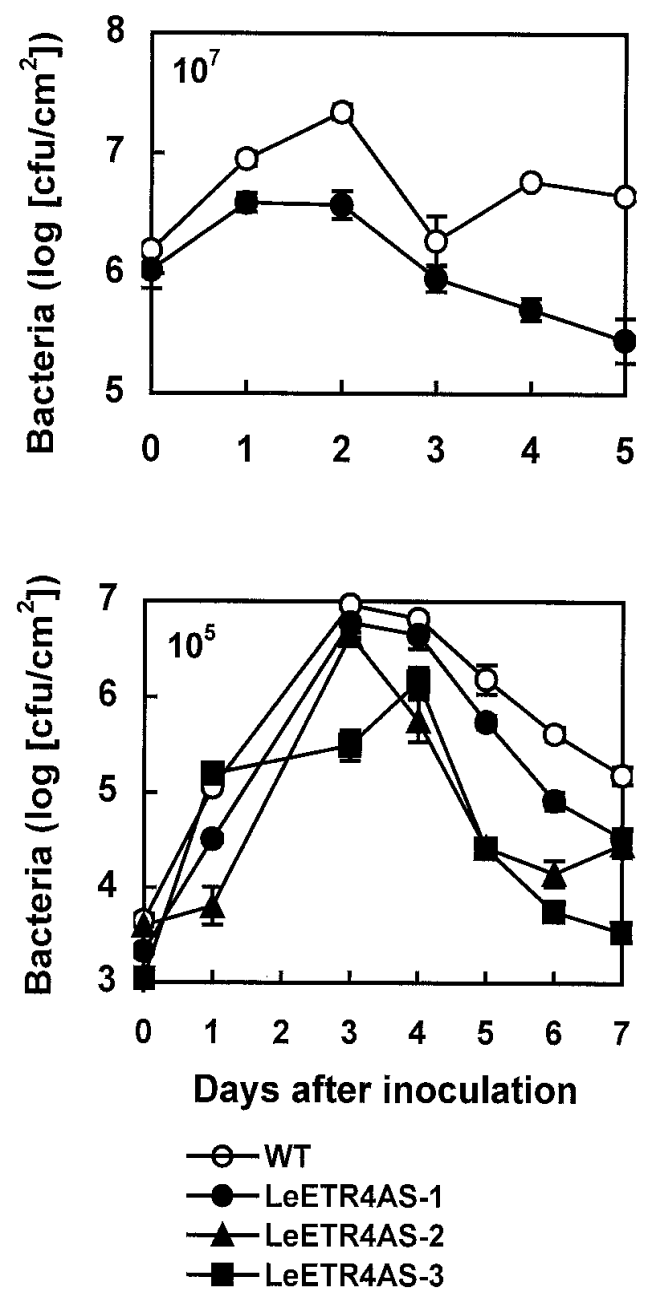

Fig. 6. Growth of avirulent Xanthomonas campestris pv. vesicatoria in leaves of wild-type and LeETR4 antisense plants. Plants were vacuum infiltrated with inoculum containing $10^{5}$ or $10^{7} \mathrm{CFU} / \mathrm{ml}$. 
with virulent and avirulent strains of $X$. campestris pv. vesicatoria. This induction, however, occurred 6 to 8 days earlier during an incompatible interaction (Ciardi et al. 2000). Taken together, these data suggest that the early induction of LeETR gene expression during an incompatible interaction could play a role in containing cell death to the site of infection.

To determine the role of LeETR gene induction during an incompatible interaction, we studied response to pathogen infection in LeETR4AS plants. Antisense expression of LeETR4 effectively reduced induction of this gene during infection with an avirulent strain of $X$. campestris pv. vesicatoria. This reduction led to an accelerated HR in the transgenic plants, as evidenced by a more rapid spread of necrosis following inoculation with high titers of bacteria $\left(10^{7}\right.$ $\mathrm{CFU} / \mathrm{ml}$ ). At $10^{6} \mathrm{CFU} / \mathrm{ml}$, the antisense plants exhibited more necrosis than the wild type, indicating that these plants were less effective in containing the spread of hypersensitive cell death. At $10^{5} \mathrm{CFU} / \mathrm{ml}$, lesion development was more rapid in the transgenic plants, indicating that LeETR4 expression affects the timing of cell death at low bacterial titers as well. Electrolyte leakage from infected leaves also increased more quickly in the antisense lines, further indicating more rapid cell damage. Therefore, induction of LeETR4 expression does appear to play a role in negatively regulating hypersensitive cell death in response to $X$. campestris pv. vesicatoria infection.

LeETR4 expression in uninfected wild-type leaves is extremely low and represents less than $10 \%$ of total ethylene receptor gene expression in this tissue (Tieman et al. 2000). Therefore, further reduction of LeETR4 mRNA levels in uninfected LeETR4AS leaves would not be expected to have a significant effect on ethylene sensitivity. In fact, developmental differences between wild-type and LeETR4AS plants were observed only in tissues with higher levels of LeETR4 mRNA such as petioles, flower buds, and fruit (Tieman et al. 2000). It is likely, then, that enhancement of the HR in LeETR4AS plants is a result of reduced induction of LeETR4 expression after infection rather than differences in ethylene sensitivity at the time of infection.

Comparison of plant response to virulent and avirulent $X$. campestris pv. vesicatoria indicates that the timing of LeETR4 induction is critical for the regulation of cell death. In wildtype plants, this induction begins 2 days after infection with the avirulent strain, but does not begin until 8 days after infection with the virulent strain (Ciardi et al. 2000). Although the level of induction is similar in compatible and incompatible interactions, increased LeETR4 expression does not limit cell death during the compatible interaction because complete necrosis still occurs. It may be that the increase in LeETR4 mRNA levels occurs too late in the compatible interaction to prevent necrosis because by the time expression of this gene has reached its peak (12 days postinfection), widespread chlorosis and necrosis already is evident. Similarly, reduction of LeETR4 mRNA levels in LeETR4AS plants increases cell death induced by avirulent $X$. campestris pv. vesicatoria but does not affect cell death induced by a virulent strain. Because the induction of LeETR4 expression during a compatible interaction does not prevent cell death, reducing this induction has no effect. The extent of cell death during a compatible interaction is reduced in the $\mathrm{Nr}$ mutant, but in this case the plant is already insensitive to ethylene at the time of infection.
Two antisense lines, LeETR4AS-1 and LeETR4AS-3, exhibited stronger and more rapid increases in ethylene synthesis and PR gene expression during infection with avirulent $X$. campestris pv. vesicatoria. Therefore, the induction of LeETR4 during infection also appears to be involved in regulating these defense responses. The third LeETR4AS line, LeETR4AS-2, did not exhibit significant differences in PR gene expression and increases in ethylene synthesis were not as great as they were in the other two lines. Differences in ethylene sensitivity among the LeETR4AS lines also were observed during developmental processes such as fruit ripening (Tieman et al. 2000). The reasons for these differences are not clear because a stronger ethylene response was not always correlated with a greater reduction of LeETR 4 mRNA levels.

The timing of a plant's defense against pathogen attack may determine whether pathogen invasion is successful. Several components of the defense response occur more quickly during incompatible interactions, including production of reactive oxygen intermediates (Keppler et al. 1989; Orlandi et al. 1992), induction of PR gene expression (Dong et al. 1991; Jia and Martin 1999; Van Kan et al. 1992), and increases in ethylene and salicylic acid levels (De Laat and Van Loon 1983, Malamy et al. 1990; Montalbini and Elstner 1977). Because increases in ethylene synthesis and PR gene expression were greater and more rapid in LeETR4AS plants, induction of LeETR4 expression during infection with $X$. campestris pv. vesicatoria may be involved in dampening the defense response. Although a rapid response is critical for limiting pathogen growth, it requires a large portion of a plant's resources. For example, Arabidopsis spp. mutants with constitutive defense such as $l s d l$, dndl, and acd6 are much smaller than wild-type plants (Dietrich et al. 1994; Rate et al. 1999; Yu et al. 1998). Increases in ethylene receptor levels may be one way of regulating the timing and magnitude of these defenses, allowing an attack sufficient to limit pathogen growth while minimizing the amount of resources used. A burst in ethylene synthesis followed by an increase in receptor levels also may allow for a rapid defense response and limit the negative effects of ethylene such as the spread of necrosis.

Avirulent $X$. campestris pv. vesicatoria population levels also decreased more quickly in the antisense lines, indicating that reduced LeETR4 expression increased resistance. This enhanced resistance may have been a result of the accelerated cell death in the transgenic lines because in wild-type and antisense plants, a decline in bacterial populations coincided with the onset of visible necrosis. The more rapid defense response, illustrated by faster increases in ethylene synthesis and PR gene expression, also may have led to stronger resistance.

Treatment with the ethylene action inhibitor MCP alleviated the accelerated HR phenotype in LeETR4AS plants, indicating that the changes in pathogen response of the transgenic plants were a result, at least in part, of an increase in ethylene sensitivity. Wild-type plants treated with MCP also exhibited a delayed HR, suggesting that decreased ethylene sensitivity can delay the HR in wild-type plants as well. Untreated ethylene-insensitive $\mathrm{Nr}$ mutant plants, however, did not exhibit this same delay in development of the HR. One possible explanation is that the MCP-treated plants are more insensitive to ethylene. For example, inhibition of seedling elongation by 
the ethylene precursor ACC revealed that etiolated wild-type seedlings treated with MCP were less sensitive to ethylene than were the $\mathrm{Nr}$ mutant seedlings (data not shown). The $\mathrm{Nr}$ mutant still shows some response to ethylene (Lanahan et al. 1994), therefore the approximately 50-fold increase in ethylene synthesis during infection may be sufficient to induce a normal ethylene response, even in the mutant plants. Although the $\mathrm{Nr}$ mutation is strong enough to inhibit cell death during a compatible interaction with $X$. campestris pv. vesicatoria, the amount of ethylene produced is much lower, less than onetenth of the 50-fold increase observed here (Ciardi et al. 2000).

Previous studies on ethylene's role in pathogenesis have focused on the effect of reduced ethylene sensitivity. The focus on ethylene insensitive mutants may explain why relatively few incompatible interactions have been identified in which ethylene appears to play a major role. The results presented here with $X$. campestris pv. vesicatoria suggest that it is the reduction in ethylene sensitivity caused by induction of ethylene receptor gene expression that contributes to the regulation of hypersensitive cell death. Therefore, the effect of inducing ethylene receptor genes during an incompatible interaction would be masked in ethylene-insensitive plants. The availability of transgenic tomato lines and Arabidopsis spp. lossof-function mutants with increased ethylene sensitivity (Hua and Meyerowitz 1998) will allow for a reevaluation of ethylene's role in plant resistance.

\section{MATERIALS AND METHODS}

\section{Plant material.}

The LeETR4AS transgenic Mill tomato lines were produced through Agrobacterium spp.-mediated transformation of cultivar Floradade, as previously described (McCormick et al. 1986; Tieman et al. 2000). All lines were homozygous for the transgene as confirmed by polymerase chain reaction amplification of the neomycin phosphotransferase gene, a selectable marker for kanamycin resistance. The homozygous $\mathrm{Nr}$ tomato mutant is isogenic with the wild-type cultivar Pearson (Rick and Butler 1956). All plants were grown under standard greenhouse conditions.

\section{Inoculations and disease development.}

Four-week-old tomato plants were inoculated with $X$. campestris pv. vesicatoria strains 87-7 (avirulent) and 93-1 (virulent). Xv 87-7 contains the avirulence gene avrBs3-2 (Bonas et al. 1993) and is avirulent on all L. esculentum cultivars tested, although it is virulent on pepper (Capsicum annuum cv. Early Calwonder) (Canteros et al. 1991). Inoculations were performed by vacuum infiltrating entire plants for $1 \mathrm{~min}$ in inoculum containing $10^{7} \mathrm{CFU} / \mathrm{ml}$ and $0.0125 \%$ (vol/vol) Silwet 77 (Lehle Seeds, Round Rock, TX, U.S.A.) in sterile tap water. For bacterial population counts, plants were also infiltrated with inoculum containing $10^{6}$ and $10^{5} \mathrm{CFU} / \mathrm{ml}$. Mock inoculations were performed by infiltrating plants with sterile tap water containing $0.0125 \%$ Silwet 77 . Plants also were inoculated by syringe infiltration in the absence of Silwet. All measurements were taken from the third and fourth leaf from the base of the plant; these were the two youngest, fully expanded leaves at the time of inoculation.
Electrolyte leakage and bacterial growth were measured as described previously (Lund et al. 1998). Ethylene was collected by placing single leaflets into sealed 5-ml containers and incubated for $1 \mathrm{~h}$ at room temperature. Ethylene concentration in a 1-ml sample was determined by a gas chromatograph (Model 5890, Hewlett-Packard, Palo Alto, CA, U.S.A.). Trypan blue staining was performed by boiling leaf discs for $1 \mathrm{~min}$ in a lactophenol solution containing equal parts water, phenol, lactic acid, and glycerol and $0.05 \%$ (wt/vol) trypan blue. Leaf discs were then destained by boiling in lactophenol in the absence of trypan blue for $3 \mathrm{~min}$ and rinsing in 50\% ethanol for $5 \mathrm{~min}$ (Rate et al. 1999).

\section{RNA isolation and quantification.}

RNA was isolated from leaflets of the third and fourth leaf from the base of the plant. RNA was extracted in sodium dodecyl sulfate-phenol and purified by $\mathrm{LiCl}$ precipitation. RNA gel blot analysis was performed as described with $10 \mu \mathrm{g}$ of total RNA (Kneissl and Deikman 1996). All DNA probes were random primer labeled with ${ }^{32} \mathrm{P}$ with the Prime-It II labeling kit (Stratagene, La Jolla, CA, U.S.A.). Templates for the PR genes were described previously (Ciardi et al. 2000). Blots were probed with labeled 18S rDNA from Zamia floridana to ensure equal levels of total RNA. LeETR4 mRNA levels were quantified by RNase protection assays (Ambion, Austin, TX, U.S.A.) with $20 \mu \mathrm{g}$ of total RNA. RNase protection assays were performed with a gene-specific probe as described (Tieman and Klee 1999).

\section{MCP treatment and seedling triple response assay.}

Four-week-old tomato plants were treated overnight with $4 \mathrm{mg}$ of MCP per liter (Ethylbloc-Floralife, Walterboro, SC, U.S.A.) in sealed glass containers (Sisler and Serek 1997). Plants were treated in the greenhouse the night before inoculation, and control plants were sealed in containers without MCP. Triple response assays were performed by growing seedlings in the dark on agar medium containing varying rates of ACC, as described (Lanahan et al. 1994). MCP-treated seedlings were grown in sealed glass containers with $4 \mathrm{mg}$ of MCP per liter, which was replaced daily, whereas control seedlings were grown in sealed glass containers in the absence of MCP.

\section{ACKNOWLEDGMENTS}

We thank M. Taylor for production and care of the LeETR4AS plants and G. Minsavage for maintenance of bacterial strains and greenhouse assistance. We also thank J. Roll for help with RNA extraction and RNA gel blot analysis. This work was supported in part by the U.S. Department of Agriculture, grant 98-35304-6667, to H. J. Klee, and the National Science Foundation, grant IBN-9728133, to H. J. Klee. This is Florida Agriculture Experiment Station journal series R-07973.

\section{LITERATURE CITED}

Bent, A. F., Innes, R. W., Ecker, J. R., and Staskawicz, B. J. 1992. Disease development in ethylene-insensitive Arabidopsis thaliana infected with virulent and avirulent Pseudomonas and Xanthomonas pathogens. Mol. Plant-Microbe Interact. 5:372-378.

Bonas, U., Conrads-Strauch, J., and Balbo, I. 1993. Resistance in tomato to Xanthomonas campestris pv. vesicatoria is determined by alleles of 
the pepper-specific avirulence gene avrBs3. Mol. Gen. Genet. 238:261-269.

Broglie, K., Chet, I., Jolliday, M., Cressman, R., Biddle, P., Knowlton, S., Mauvais, C. J., and Broglie R. 1991. Transgenic plants with enhanced resistance to the fungal pathogen Rhizoctonia solani. Science 254:1194-1197.

Canteros, B., Minsavage, G., Bonas, U., Pring, D., and Stall R. 1991. A gene from Xanthomonas campestris pv. vesicatoria that determines avirulence in tomato is related to avrBs3. Mol. Plant-Microbe Interact. 4:628-632.

Chang, C., Kwok, S. F., Bleecker, A. B., and Meyerowitz, E. M. 1993. Arabidopsis ethylene response gene ETR1-similarity of product to two-component regulators. Science 262:539-544.

Ciardi, J. A., Tieman, D. M., Lund, S. T., Jones, J. B., Stall, R. E., and Klee, H. J. 2000. Response to Xanthomonas campestris pv. vesicatoria in tomato involves regulation of ethylene receptor gene expression. Plant Physiol. 123:81-92.

De Laat, A. M. M., and Van Loon, L. C. 1983. The relationship between stimulated ethylene production and symptom expression in virusinfected tobacco leaves. Physiol. Plant Pathol. 22:261-273.

Delledonne, M., Xia, Y., Dixon, R. A., and Lamb, C. 1998. Nitric oxide functions as a signal in plant disease resistance. Nature 394:585-588.

Dietrich, R. A., Delaney, T. P., Uknes, S. J., Ward, E. R., Ryals, J. A., and Dangl, J. L. 1994. Arabidopsis mutants simulating disease resistance response. Cell 77:565-577.

Dong, X., Mindrinos, M., Davis, K. R., and Ausubel, F. M. 1991. Induction of Arabidopsis thaliana defense genes by virulent and avirulent Pseudomonas syringae strains and by a cloned avirulence gene. Plant Cell 3:61-72

Glazener, J. A., Orlandi, E. W., and Baker, C. J. 1996. The active oxygen response of cell suspensions to incompatible bacteria is not sufficient to cause hypersensitive cell death. Plant Physiol. 110:759-763.

Goodman, R. N., and Novacky, A. J. 1994. The Hypersensitive Reaction in Plants to Pathogens: A Resistance Response. American Phytopathological Society, St. Paul, MN, U.S.A.

Grbic, V., and Bleecker, A. B. 1995. Ethylene regulates the timing of leaf senescence in Arabidopsis. Plant J. 8:595-602.

He, C. J., Morgan, P. W., and Drew, M. C. 1996. Transduction of an ethylene signal is required for cell death and lysis in the root cortex of maize during aerenchyma formation induced by hypoxia. Plant Physiol. 112:463-472.

Hoffman, T., Schmidt, J. S., Zheng, X., and Bent, A. F. 1999. Isolation of ethylene-insensitive soybean mutants that are altered in pathogen susceptibility and gene-for-gene disease resistance. Plant Physiol. 119:935-949.

Hua, J., and Meyerowitz, E.M. 1998. Ethylene responses are negatively regulated by a receptor gene family in Arabidopsis thaliana. Cell 94:261-271.

Hua, J., Chang, C., Sun, Q., and Meyerowitz, E. M. 1995. Ethylene insensitivity conferred by Arabidopsis ERS gene. Science 269:17121714.

Hua, J., Sakai, H., Nourizadeh, S., Chen, Q. G., Bleecker, A. B., Ecker, J. R., and Meyerowitz, E. M. 1998. EIN4 and ERS2 are members of the putative ethylene receptor gene family in Arabidopsis. Plant Cell 10:1321-1332.

Jabs, T., Tschope, M., Colling, C., Hahlbrock, K., and Scheel, D. 1997. Elicitor-stimulated ion fluxes and $\mathrm{O}_{2}$ from the oxidative burst are essential components in triggering defense gene activation and phytoalexin synthesis in parsley. Proc. Natl. Acad. Sci. USA 94:4800-4805.

Jia, Y. L., and Martin, G. B. 1999. Rapid transcript accumulation of pathogenesis-related genes during an incompatible interaction in bacterial speck disease-resistant tomato plants. Plant Mol. Biol. 40:455-465.

Keppler, L. D., Baker, C. J., and Atkinson, M. M. 1989. Active oxygen production during a bacteria-induced hypersensitive reaction in tobacco suspension cells. Phytopathology 79:974-978.

Kneissl, M. L., and Deikman, J. 1996. The tomato $E 8$ gene influences ethylene biosynthesis in fruit but not in flowers. Plant Physiol. 112:537-547.

Lanahan, M. B., Yen, H.-C., Giovannoni, J. J., and Klee, H. J. 1994. The Never ripe mutation blocks ethylene perception in tomato. Plant Cell 6:521-530.
Lashbrook, C. C., Tieman, D. M., and Klee, H. J. 1998. Differential regulation of the tomato ETR gene family throughout plant development. Plant J. 15:243-252.

Levine, A., Tenhaken, R., Dixon, R., and Lamb, C. 1994. $\mathrm{H}_{2} \mathrm{O}_{2}$ from the oxidative burst orchestrates the plant hypersensitive disease resistance response. Cell 79:583-593.

Ligterink, W., Kroj, T., Nieden, U., Hirt, H., and Scheel, D. 1997. Receptor-mediated activation of a MAP kinase in pathogen defense of plants. Science 276:2054-2057.

Linthorst, H. J. M. 1991. Pathogenesis-related proteins in plants. Crit. Rev. Plant Sci. 10:123-150.

Lund, S. T., Stall, R. E., and Klee, H. J. 1998. Ethylene regulates the susceptible response to pathogen infection in tomato. Plant Cell 10:371-382.

Malamy, J., Carr, J. P., Klessig, D. F., and Raskin, I. 1990. Salicylic acid: A likely endogenous signal in the resistance response of tobacco to viral infection. Science 250:1002-1004.

McCormick, S., Neidermeyer, J., Fry, J., Barnason, A., Horsch, R., and Fraley, R. 1986. Leaf disc transformation of cultivated tomato (L. esculentum) using Agrobacterium tumefaciens. Plant Cell Rep. 5:81-84.

McDowell, J. M., and Dangl, J. L. 2000. Signal transduction in the plant immune response. Trends Biochem. Sci. 25:79-82.

Mittler, R., Shulaev, V., and Lam, E. 1995. Coordinated activation of programmed cell death and defense mechanisms in transgenic tobacco plants expressing a bacterial proton pump. Plant Cell 7:29-42.

Montalbini, P., and Elstner, E. F. 1977. Ethylene evolution by rustinfected, detached bean (Phaseolus vulgaris L.) leaves susceptible and hypersensitive to Uromyces phaseoli (Pers.) Wint. Planta 135:301-306

Orlandi, E. W., Hutcheson, S. W., and Baker, C. J. 1992. Early physiological responses associate with race-specific recognition in soybean leaf tissue and cell suspensions treated with Pseudomonas syringae pv. glycinea. Physiol. Mol. Plant Pathol. 40:173-80.

Rate, D. N., Cuenca, J. V., Bowman, G. R., Guttman, D. S., and Greenberg, J. T. 1999. The gain-of-function Arabidopsis acd6 mutant reveals novel regulation and function of the salicylic acid signaling pathway in controlling cell death, defenses, and cell growth. Plant Cell 11:1695-1708.

Rick, C., and Butler, L. 1956. Phytogenetics of the tomato. Adv. Genet. 8:267-382.

Romeis, T., Piedras, P., Zhang, S., Klessig, D. F., Hirt, H., and Jones, J. D. G. 1999. Rapid avr9-and Cf-9-dependent activation of MAP kinases in tobacco cell cultures and leaves: convergence of resistance gene, elicitor, wound and salicylate responses. Plant Cell 11:273-287.

Shirasu, K., Nakajima, H., Rajasekhar, V. K., Dixon, R. A., and Lamb, C. 1997. Salicylic acid potentiates an agonist-dependent gain control that amplifies pathogen signals in the activation of defense mechanisms. Plant Cell 9:261-270.

Sisler, E. C., and Serek, M. 1997. Inhibitors of ethylene responses in plants at the receptor level: Recent developments. Physiol. Plant $100: 577-582$

Thomma, B. P. H. J., Eggermont, K., Tierens, K. F. M. J., and Broekaert, W. F. 1999. Requirement of functional Ethylene-Insensitive 2 gene for efficient resistance of Arabidopsis to infection by Botrytis cinerea. Plant Physiol. 121:1093-1101.

Tieman, D. M., and Klee, H. J. 1999. Differential expression of two novel members of the tomato ethylene receptor family. Plant Physiol. 120:165-172.

Tieman, D. M., Taylor, M. G., Ciardi, J. A., and Klee, H. J. 2000. The tomato ethylene receptors NR and LeETR4 are negative regulators of ethylene response and exhibit functional compensation within a multigene family. Proc. Natl. Acad. Sci. USA 97:5663-5668.

Van Kan, J. A. L, Joosten, M. H. A. J., Wagemakers, C. A. M., Van den Berg-Velthius, G. C. M., and De Wit, P. J. G. M. 1992. Differential accumulation of mRNAs encoding extracellular and intracellular PR proteins in tomato induced by virulent and avirulent races of $\mathrm{Cla}$ dosporium fulvum. Plant Mol. Biol. 20:513-527.

Wilkinson, J. Q., Lanahan, M. B., Yen, H.-C., Giovannoni, J. J., and Klee, H. J. 1995. An ethylene-inducible component of signal transduction encoded by Never-ripe. Science 270:1807-1809.

Young, T. E., and Gallie, D. R. 1999. Analysis of programmed cell death in wheat endosperm reveals differences in endosperm development 
between cereals. Plant Mol. Biol. 39:915-926.

Yu, I. C., Parker, J., and Bent, A. F. 1998. Gene-for gene disease resistance without the hypersensitive response in Arabidopsis dnd $1 \mathrm{mu}-$ tant. Proc. Natl. Acad. Sci. USA 95:7819-7824.

Zhou, J., Loh, Y. T., Bressan, R. A., and Martin, G. B. 1995. The tomato gene Ptil encodes a serine/threonine kinase that is phospho- rylated by Pto and is involved in the hypersensitive response. Cell 83:925-935.

Zhu, Q., Maher, E. A., Maoud, S., Dixon, R. A., and Lamb, C. J. 1994. Enhanced protection against fungal attack by constitutive coexpression of chitinase and glucanase genes in transgenic tobacco. Bio/Technology 12:807-812. 